\title{
Hydrological and Ichthyological Impact Assessment of Rasul Barrage, River Jhelum, Pakistan
}

\author{
Hafiza Hira Iqbal ${ }^{1}$, Naeem Shahid ${ }^{2}$, Abdul Qadir ${ }^{1 *}$, Sajid Rashid Ahmad", \\ Saba Sarwar ${ }^{1}$, Muhammad Rizwan Ashraf ${ }^{3}$, Hafiz Muhammad Arshad ${ }^{4}$, Nasir Masood ${ }^{2}$ \\ ${ }^{1}$ College of Earth and Environmental Sciences, University of the Punjab, Lahore, Pakistan \\ ${ }^{2}$ Department of Environmental Sciences, COMSATS Institute of Information Technology, 61100 Vehari, Pakistan \\ ${ }^{3}$ University of Agriculture Faisalabad, Sub-campus Burewala-Vehari, Seed Farm Road, 61100 Vehari, Pakistan \\ ${ }^{4}$ Department of Management Sciences, COMSATS Institute of Information Technology, Sahiwal, Pakistan
}

Received: 28 May 2016

Accepted: 25 June 2016

\begin{abstract}
Over the years surface water quality of Pakistani rivers has been degraded. The current study aims to investigate the water quality and fish diversity at Rasul Barrage in the Jhelum River. A total of six sampling sites were assessed for pollution levels and fish fauna of the Barrage. Physicochemical parameters such as turbidity, biological oxygen demand (BOD), and chemical oxygen demand (COD) were deviating from the permissible limits of fresh water set by the U.S. Environmental Protection Agency (EPA), but meeting the criteria of NEQS, whereas $\mathrm{pH}$, temperature, electrical conductivity (EC), total dissolved solids (TDS), total suspended solids (TSS), sodium, and chloride were below the permissible limits of NEQS, but the TSS level was above EPA standards. However, the concentrations of metals such as iron (2.62-3.98 $\left.\mathrm{mg} \mathrm{L}^{-1}\right)$, chromium (0.03-0.59 $\left.\mathrm{mg} \mathrm{L}^{-1}\right)$, and nickel (0.49-1.71 $\left.\mathrm{mg} \mathrm{L}^{-1}\right)$ were higher than the permissible limits for drinking and irrigation waters. In addition, a total of 35 fish species belonging to eight families were identified. Survey and result of study showed that concentrations of pollutants and non-stop fishing activities of commercial fish are the main reasons for the reduction of fish fauna. Two exotic fish species, Oreochromismossambicus and Ctenopharyngodon idella, were found to be abundant where population of native fish fauna numbers were being reduced. We concluded that the surface water quality is poor, as is evident from the higher concentrations of BOD, COD, and metals. Urgent measures are required to prevent such contamination and regular monitoring of water quality in the study area.
\end{abstract}

Keywords: water contamination, metals content, drinking water, health problems, fish fauna

*e-mail: aqadir.cees@pu.edu.pk, qadir.qau@gmail.com 


\section{Introduction}

The toxic metal contamination of freshwater ecosystems is a serious worldwide environmental problem [1-3]. Degrading water quality, particularly in developing countries, poses deleterious effects on aquatic life and threats to human health [4-5]. Large amounts of contaminants comprising toxic metals, pathogens, persistent organic pollutants, and pharmaceutical drugs are being discharged at high volumes into urban river systems [6]. It has been suggested that rapid urbanization, industrialization, and agricultural activities are major contributors to river pollution. Metals in aquatic ecosystem become integrated into the food web, causing harmful effects to aquatic life and humans [2, 7-8]. Significant amounts of heavy metals can lead to harmful diseases such as cancer, mental disorders, and kidney and cardiovascular syndromes [9-12]. Previous studies have revealed that rivers and streams, particularly in developing countries, are being severely contaminated due to the disposal of untreated industrial effluents and municipal wastewater, as well as uncontrolled agricultural runoff in water bodies [13-16].

Pakistan is a developing country facing surface water pollution [17-19] that may cause serious threats to aquatic life. Aquatic organisms quickly respond to minor changes in the environment that reflect the health status of a water ecosystem [20]. Fish are an important and sensitive member of the aquatic food web. Most of their species are confined to live in microhabitats; however, when these habitats get contaminated, a variety of fish species either moves to less polluted areas or dies. Moreover, the presence of heavy metals may pose lethal or chronic effects on fish fauna [21-23]. Toxic effects are increased when different metabolic activities fail to detoxify the metals in the body of an organism.

\section{Study Area}

The Rasul Barrage Reservoir (Fig. 1) provides a good habitat for fish [24]. It is located on Jhelum River, one of the largest tributaries of the Indus River that irrigates the plains of Punjab. It receives water from different glaciers located in northern Kashmir; however, due to the long distance between Kashmir and Rasul Berrage, a lot of contaminants are mixed, altering water quality [25]. Resultantly, the contamination of water in addition to illegal fishing create disturbances to natural fish assemblages. There have been very few studies conducted to assess water quality and the ichthyofauna of Rasul Barrage [24, 26].

Keeping in mind the above-mentioned problems, the following study was conducted to determine the quality of water and distribution of fish density in the reservoir. The results of the present study give an overview of water quality and fish fauna in Pakistani rivers. Our main attempt is to provide an understanding of the dynamics of fish assemblages influenced by anthropogenic activities with a purpose of achieving sustainable fish resources.

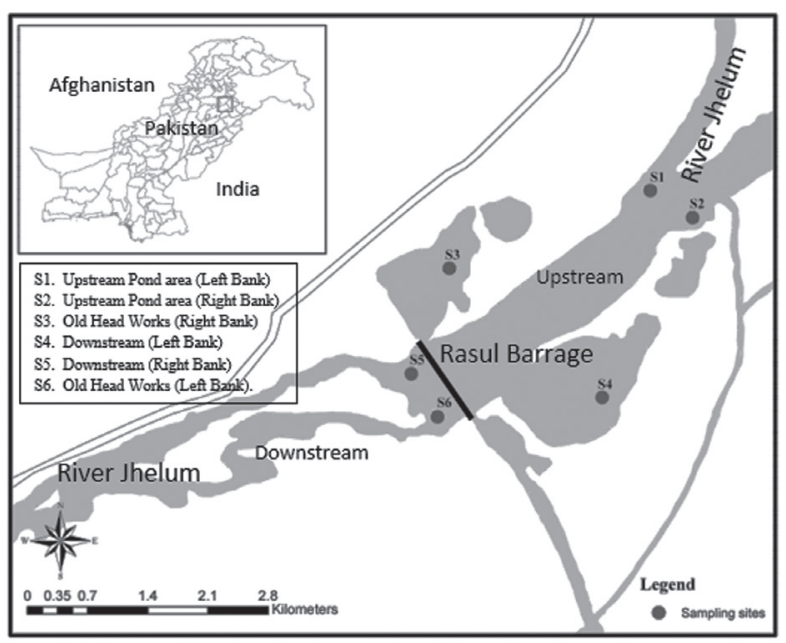

Fig. 1. Map of the study area showing sampling sites.

\section{Materials and Methods}

A total of 18 samples were taken from six sampling sites, consisting of two locations from the old headworks (right and left banks), two from downstream (right and left banks), and the remaining two from the upstream pond area (right and left banks).

\section{Water Sampling}

Water samples were collected on 10 April 2013 as per the standard method of sampling and examination of water given by the American Public Health Association [27]. Sterilized plastic bottles of $500 \mathrm{~mL}$ volume were used for water sampling. The samples were subsequently transferred to the laboratory at the College of Earth and Environmental Sciences and preserved in a refrigerator at $4^{\circ} \mathrm{C}$.

\section{Physicochemical Parameters Analysis}

Water samples were analyzed for physicochemical parameters such as temperature, total dissolve solid (TDS), total suspended solid (TSS), turbidity, $\mathrm{pH}$, hardness, chlorides $(\mathrm{Cl})$, dissolve oxygen (DO), electrical conductivity (EC), biological oxygen demand (BOD), chemical oxygen demand (COD), carbonates $\left(\mathrm{CO}_{3}\right)$, bicarbonates $\left(\mathrm{HCO}_{3}\right)$, potassium $(\mathrm{K})$, sodium $(\mathrm{Na})$, and the heavy metals chromium $(\mathrm{Cr})$, iron $(\mathrm{Fe})$, copper $(\mathrm{Cu})$, and nickel (Ni). $\mathrm{pH}$, temperature, conductivity and $\mathrm{DO}$ were measured in situ; other factors were analyzed in laboratory.

\section{Heavy Metals Analysis}

For the analysis of heavy metals, a $20 \mathrm{~mL}$ volume of each water sample was treated with a mixture of $\mathrm{H}_{2} \mathrm{O}_{2}$ and $\mathrm{HNO}_{3}$ acids in 2:5 ratios $\left(2 \mathrm{~mL} \mathrm{H}_{2} \mathrm{O}_{2}\right.$ and $\left.5 \mathrm{~mL} \mathrm{HNO}_{3}\right)$ in a closed Teflon vessel followed by digestion in a microwave 
digestion system [28]. Subsequently, the digested solutions were filtered (pore size $=0.45 \mathrm{~m}$ ) and stored in $50 \mathrm{~mL}$ plastic bottles. The concentration of metals was determined using a graphite furnace atomic absorption spectrophotometer (Perkins Elmer-700) in the College of Earth and Environmental Sciences.

\section{Fish Sampling}

The fish were collected from six selected sampling sites (mentioned previously) using different methods, i.e., gill nets (1-4 inches) and cast nets [29-30]. The fish catch data and habitat descriptions for each sampling site were also used to determine the pattern of distribution in fish assemblage. Each site was selected on the basis of different characteristics of aquatic habitat such as open water, riparian vegetation, and emergent macrophytes. A standard length of $50 \mathrm{~m}$ - covering the maximum number of representative habitats - was used to obtain a representative sample.

Fish specimens were collected, identified, and photographed on site, whereas the number of specimens of each species was also counted [31]. The specimens were identified by following regional keys [32]. The voucher specimens were kept for record and preserved in $10 \%$ formaldehyde. Fish abundance data recorded during the survey was further subjected to statistical analysis.

\section{Statistical Analysis}

The fish data was analyzed by different methods such as diversity indices, the Shannon and Simpson index, and cluster analysis (CA) techniques. Diversity indices provide information about species distribution and abundance status of species in a community. These diversity indices are important tools for biologists to understand fish assemblage. Various diversity indices are in use by many ecologists. The Shannon index $\left(\mathrm{H}^{\prime}\right)$ and Simpson index (D) techniques were used to calculate fish species diversity using PCOrd 4 [33], whereas cluster analysis (CA) was carried out using PAST (version 2.17) to determine the similarity among different water bodies on the basis of the distribution of fish fauna. Furthermore, correlation statistics were used to determine the relationships among heavy metals and fish abundance.

\section{Results}

\section{Physicochemical Parameters}

The results of physicochemical parameters, including $\mathrm{pH}$, temperature, EC, turbidity, hardness, DO, BOD, COD, TDS, and TSS of water samples are summarized in Table 1. The $\mathrm{pH}, \mathrm{EC}$, and temperature ranged between 7.0 to $7.4,20.2$ to $26.1^{\circ} \mathrm{C}$, and 250 to $349 \mu \mathrm{S} \mathrm{cm}{ }^{-1}$, respectively. The parameters were in permissible limits, hence water quality can be considered safe for domestic and agricultural purposes. Nevertheless, the level of $\mathrm{pH}$ in the present study $(\sim 7.25)$ was higher than the previous study conducted on the Jhelum $(\sim 7.18)$ in the same season [25]. However, it is suggested that the $\mathrm{pH}$ level cannot be selected as accepted criteria for irrigation water quality as the soil has the ability to buffer it due to [34]. Besides, it has been suggested that the conductivity is directly related to total dissolved solids [35]. The level of TDS was under the permissible limits, ranging from 209 to $440 \mathrm{mg} \mathrm{L}^{-1}$, with a mean value of $363 \mathrm{mg} \mathrm{L}^{-1}$. Total dissolved solids are considered a major factor for the taste of water and for growth of plants [36-37]; therefore, the water of Rasul Barrage is suitable for irrigation. The level of TDS depends on several factors such as the geological character of the watershed, rainfall, and the amount of surface runoff.

The turbidity level ranged between 56 NTU to 85 NTU, which is higher than the standard permissible limits set by the U.S. EPA, the Pakistani EPA, and the World Health Organization. The highest value (85 NTU) was recorded at the old headwork right bank, whereas the lowest (56 NTU) was observed at the pond area left bank. The high turbidity level at the old headworks might be attributed to soil erosion, surface runoff, and the contribution of suspended solids from domestic wastes [38]. Suspended solids are fine particles of organic and inorganic nature and considered pollutants. Total suspended solids in river water samples ranged from $65 \mathrm{mg}$ to $268 \mathrm{mg} \mathrm{L}^{-1}$, with the highest value at the old headworks left bank and the lowest at the pond area left bank. The values of TSS were within acceptable limits set by the National Environmental Quality Standards (NEQS) but exceeded U.S. EPA limits. Enhanced TSS levels can lead to changes in physical, chemical, and biological properties of waterbodies. Furthermore, it can cause water quality deterioration that leads to severe ecological degradation and a decline in fisheries resources [39]. In-situ decomposition of SS can reduce the DO level, creating a serious oxygen shortage that may lead to fish kills during low-flow conditions [40]. Furthermore, higher levels of suspended solids may cause adverse effects on agriculture by the formation of soil crust, inhibiting seed emergence, reducing soil aeration, and reducing the rate of photosynthesis $[39,41]$.

The levels of DO, COD, and BOD were within acceptable limits set by NEQS. The DO was found to be in the range 6.0 to $9.3 \mathrm{mg} \mathrm{L}^{-1}$ with the lowest level (6.0 $\left.\mathrm{mg} \mathrm{L}^{-1}\right)$ at the old head work left bank, while the highest was at the pond area left bank. On the basis of DO, water samples of Rasul Barrage were categorized as non-polluted ( $\mathrm{DO} \geqq 6.5)$. It is suggested that the lower DO level at the old head work left bank might be due to higher levels of TSS and low flow conditions [42]. It is considered that the behaviors of BOD and COD are opposite that of DO. The levels of BOD and COD ranged between 31.8 to 54.8 and 61.3 to $104 \mathrm{mg} \mathrm{L}^{-1}$, respectively. BOD values were lesser than the COD values due to the presence of biologically resistant organic matter. The highest values of these two parameters were recorded at the old head work left bank, whereas the lowest were at the pond area left bank, but remained within permissible limits set by NEQS but polluted according to the U.S. EPA. 
Table 1. Physicochemical parameters of Rasul Barrage water in the Jhelum River.

\begin{tabular}{|c|c|c|c|c|c|c|c|c|c|}
\hline \multirow{2}{*}{ Site } & \multirow{2}{*}{$\mathrm{pH}$} & Temp & $\mathrm{EC}$ & Turbidity & DO & BOD & COD & TDS & TSS \\
\hline & & ${ }^{\circ} \mathrm{C}$ & $\mu \mathrm{S} \mathrm{cm}^{-1}$ & NTU & \multicolumn{5}{|c|}{$\mathrm{mg} \mathrm{L}^{-1}$} \\
\hline $\mathrm{S} 1$ & 7.0 & 25.9 & 349 & 83 & 6 & 54.8 & 104 & 440 & 268 \\
\hline $\mathrm{S} 2$ & 7.2 & 25.8 & 330 & 85 & 6.2 & 54.1. & 101 & 456 & 263 \\
\hline $\mathrm{S} 3$ & 7.2 & 22.2 & 250 & 56 & 9.3 & 31.8 & 61.3 & 209 & 65 \\
\hline S4 & 7.2 & 20.2 & 260 & 60 & 7.5 & 32.8 & 61.6 & 250 & 100 \\
\hline S5 & 7.4 & 25.6 & 349 & 80 & 6.2 & 53.7 & 98.1 & 417 & 252 \\
\hline S6 & 7.4 & 26.1 & 347 & 81 & 6.3 & 54.7 & 102 & 410 & 260 \\
\hline
\end{tabular}

Table 2. Cation and anion contents in Rasul Barrage water in the Jhelum River.

\begin{tabular}{|c|c|c|c|c|c|c|c|c|}
\hline \multirow{2}{*}{ Site } & Calcium & Magnesium & Sodium & Potassium & Carbonate & \multicolumn{2}{|c|}{ Bicarbonate } & Chloride \\
\cline { 2 - 9 } & \multicolumn{7}{|c|}{$\mathrm{mg} \mathrm{L}^{-1}$} \\
\hline S1 & 55 & 45 & 37 & 8.1 & 9.0 & 13 & 44 \\
\hline S2 & 54 & 44 & 39 & 8.3 & 9.5 & 14 & 41 \\
\hline S3 & 45 & 37 & 25 & 7.3 & 3.0 & 6.0 & 33 \\
\hline S4 & 40 & 36 & 24 & 7.1 & 4.0 & 7.0 & 37 \\
\hline S5 & 53 & 42 & 28 & 8.4 & 6.0 & 8.0 & 45 \\
\hline S6 & 51 & 43 & 40 & 8.6 & 6.5 & 9.0 & 49 \\
\hline
\end{tabular}

\section{Cations and Anions}

The results of cations $\mathrm{Ca}, \mathrm{Mg}, \mathrm{Na}$, and $\mathrm{K}$ were found to be in the range of 40 to $55 \mathrm{mg} \mathrm{L}^{-1}, 45$ to $36 \mathrm{mg} \mathrm{L}^{-1}, 24$ to $40 \mathrm{~L}^{-1}$, and 7.1 to $8.6 \mathrm{~L}^{-1}$, respectively (Table 2 ). There are no suggested standards of $\mathrm{Ca}$ and $\mathrm{Mg}$ for drinking and irrigation water. Moreover, the total concentrations of $\mathrm{Ca}$ and $\mathrm{Mg}$ are referred to as hardness and it was observed that the total hardness was within standard limits of the Pakistani EPA (500 $\left.\mathrm{mg} \mathrm{L}^{-1}\right)$. However, the average concentration of $\mathrm{Na}\left(32 \mathrm{mg} \mathrm{L}^{-1}\right)$ was not within the standard limits described by the U.S. EPA $\left(26 \mathrm{mg} \mathrm{L}^{-1}\right)$ for drinking water, but was suitable according to FAO guidelines for irrigation $\left(<69 \mathrm{mg} \mathrm{L}^{-1}\right)$. In addition, the concentration of some anions such as carbonates, bicarbonates, and chlorides ranged between 3 to $9 \mathrm{mg} \mathrm{L}^{-1}, 6$ to $14 \mathrm{mg} \mathrm{L}^{-1}$, and 33 to $49 \mathrm{mg} \mathrm{L}^{-1}$, respectively. Concentrations of all these anions were found to be under permissible limits set by the U.S. EPA, the Pakistani EPA, WHO, and NEQS for drinking water, as well as FAO guidelines for irrigation water.

\section{Heavy Metals}

Results illustrated that the concentration of heavy metals $\mathrm{Cr}, \mathrm{Cu}, \mathrm{Ni}$, and $\mathrm{Fe}$ were found to be higher than the permissible limits. $\mathrm{Cr}$ and $\mathrm{Ni}$ were recorded in the range 0.03 to $0.59 \mathrm{mg} \mathrm{L}^{-1}$ and 0.49 to $1.71 \mathrm{mg} \mathrm{L}^{-1}$, respectively. The highest $\mathrm{Cr}$ concentration was recorded at the old head work left bank, whereas the lowest was at the pond area left bank. The average concentrations of $\mathrm{Cr}$ and $\mathrm{Ni}$ were found to be higher than the standard limits set by the U.S. EPA, the Pakistani EPA, and WHO, but Cr was less than the acceptable limit of NEQS for drinking water. Furthermore, according to FAO guidelines the levels of theses metals were not suitable for irrigation purposes. The higher concentration of $\mathrm{Cr}$ might be attributed to anthropogenic activities such as effluents from dyeing and tanning industries [43-44] or naturally due to weathering of crustal materials [45-46]. In contrast, Sarwar et al. [25] reported a lower concentration of $\mathrm{Cr}(0.44 \mathrm{mg}$ $\left.\mathrm{L}^{-1}\right)$ in Jhelum River water. The difference between $\mathrm{Cr}$ concentrations of both studies can be due to the change in location and/or season. Therefore, higher contents of $\mathrm{Cr}$ in the water of Rasul Barrage render it least suitable for drinking and irrigation purposes.

Table 3. Heavy metals concentrations in Rasul Barrage water in the Jhelum River.

\begin{tabular}{|c|c|c|c|c|}
\hline \multirow{2}{*}{ Location } & Iron & Chromium & Copper & Nickel \\
\cline { 2 - 5 } & \multicolumn{4}{|c|}{$\mathrm{Mg} \mathrm{L}^{-1}$} \\
\hline S1 & 3.98 & 0.59 & 0.69 & 1.71 \\
\hline S2 & 3.90 & 0.49 & 0.51 & 1.59 \\
\hline S3 & 2.62 & 0.03 & 0.33 & 0.49 \\
\hline S4 & 2.84 & 0.04 & 0.42 & 0.01 \\
\hline S5 & 3.86 & 0.38 & 0.62 & 1.64 \\
\hline S6 & 3.93 & 0.48 & 0.58 & 1.03 \\
\hline
\end{tabular}


Table 4. Fish distribution and abundance data collected from Rasul Barrage.

\begin{tabular}{|c|c|c|c|c|c|c|c|c|c|c|}
\hline $\mathrm{Sr} \#$ & Family & Species & Status & $\mathrm{S} 1$ & $\mathrm{~S} 2$ & $\mathrm{~S} 3$ & $\mathrm{~S} 4$ & S5 & S6 & R.A \\
\hline 1 & Clupeidae & Gudisia chapra & Abundant & 1 & 0 & 6 & 12 & 5 & 6 & 5.34 \\
\hline 2 & Notopteridae & Notopterus notopterus & Common & 2 & 0 & 7 & 3 & 2 & 0 & 2.49 \\
\hline 3 & \multirow{20}{*}{ Cyprinidae } & Chela cachius & Less common & 0 & 2 & 0 & 0 & 0 & 3 & 0.89 \\
\hline 4 & & Salmophasia bacaila & Abundant & 6 & 8 & 14 & 19 & 9 & 7 & 11.21 \\
\hline 5 & & Securicula gora & Abundant & 4 & 0 & 6 & 2 & 7 & 0 & 3.38 \\
\hline 6 & & Amblypharyngodon mola & Common & 7 & 4 & 3 & 0 & 0 & 0 & 2.49 \\
\hline 7 & & Esomus danricus & Less common & 0 & 0 & 4 & 0 & 0 & 3 & 1.25 \\
\hline 8 & & Cirrhinus mrigala & Common & 4 & 0 & 5 & 3 & 0 & 3 & 2.67 \\
\hline 9 & & Cirrhinus reba & Abundant & 0 & 0 & 2 & 9 & 6 & 8 & 4.45 \\
\hline 10 & & Gibelion catla & Rare & 0 & 0 & 1 & 0 & 0 & 1 & 0.36 \\
\hline 11 & & Labeo calbasu & Abundant & 0 & 0 & 6 & 7 & 3 & 2 & 3.20 \\
\hline 12 & & Labeo dyocheilus & Abundant & 0 & 0 & 12 & 5 & 0 & 0 & 3.02 \\
\hline 13 & & Labeo gonius & Less common & 3 & 0 & 5 & 2 & 0 & 0 & 1.78 \\
\hline 14 & & Ctenopharyngodon idella & Less common & 0 & 4 & 0 & 0 & 0 & 1 & 0.89 \\
\hline 15 & & Labeo rohita & Less common & 1 & 0 & 1 & 5 & 0 & 3 & 1.78 \\
\hline 16 & & Osteobrama cotio & Abundant & 8 & 0 & 18 & 23 & 13 & 9 & 12.63 \\
\hline 17 & & Puntius sophore & Abundant & 4 & 8 & 0 & 2 & 11 & 6 & 5.52 \\
\hline 18 & & Puntius ticto & Abundant & 7 & 6 & 0 & 0 & 10 & 5 & 4.98 \\
\hline 19 & & Puntius terio & Abundant & 0 & 7 & 0 & 0 & 6 & 4 & 3.02 \\
\hline 20 & & Systomus sarana & Less common & 0 & 5 & 0 & 0 & 3 & 2 & 1.78 \\
\hline 21 & & Crossocheilus diplocheilus & Less common & 0 & 0 & 2 & 4 & 0 & 0 & 1.07 \\
\hline 22 & & Cyprinus carpio & Less common & 3 & 1 & 5 & 2 & 0 & 0 & 1.96 \\
\hline 23 & \multirow{4}{*}{ Bagridae } & Sperata sarwari & Less common & 0 & 0 & 2 & 1 & 0 & 2 & 0.89 \\
\hline 24 & & Mystus cavasius & Abundant & 0 & 5 & 6 & 3 & 3 & 1 & 3.20 \\
\hline 25 & & Mystus vittatus & Abundant & 8 & 7 & 0 & 0 & 2 & 6 & 4.09 \\
\hline 26 & & Rita rita & Less common & 0 & 0 & 0 & 2 & 0 & 1 & 0.53 \\
\hline 27 & \multirow{2}{*}{ Sisoridae } & Bagarius fbagarius & Rare & 0 & 0 & 2 & 0 & 0 & 0 & 0.36 \\
\hline 28 & & Gagata cenia & Abundant & 4 & 0 & 9 & 4 & 0 & 0 & 3.02 \\
\hline 29 & \multirow{3}{*}{ Siluridae } & Ompok pabda & Less common & 0 & 0 & 2 & 3 & 1 & 2 & 1.42 \\
\hline 30 & & Ompok bimaculatus & Abundant & 3 & 8 & 0 & 6 & 3 & 2 & 3.91 \\
\hline 31 & & Wallago attu & Common & 0 & 0 & 2 & 1 & 5 & 4 & 2.14 \\
\hline 32 & Heteropneustidae & Heteropneustes fossilis & Less common & 0 & 1 & 0 & 0 & 0 & 3 & 0.71 \\
\hline 33 & \multirow{3}{*}{ Schilbeidae } & Ailia coila & Less common & 0 & 0 & 8 & 1 & 0 & 0 & 1.60 \\
\hline 34 & & Clupisoma garua & Less common & 0 & 0 & 5 & 2 & 0 & 0 & 1.25 \\
\hline 35 & & Clupisoma naziri & Less common & 0 & 0 & 1 & 3 & 0 & 0 & 0.71 \\
\hline
\end{tabular}

The Fe concentration ranged between 2.62 to $3.98 \mathrm{mg}$ $\mathrm{L}^{-1}$, showing its highest value at the old head work left bank and the lowest at the pond area left bank. The average concentration of $\mathrm{Fe}\left(3.52 \mathrm{mg} \mathrm{L}^{-1}\right)$ exceeded the U.S. EPA standard limits for drinking water, whereas, according to
FAO guidelines, it was suitable for irrigation purposes but can be harmful to humans and livestock if directly consumed. It is suggested that the higher concentration of $\mathrm{Fe}$ might be due to weathering of crustal materials. Furthermore, it can be due to industrial effluents and 
municipal sewage from nearby cities. Results of the study were in line with previous studies conducted in Pakistan $[20,25,47]$ and India [48].

Simultaneously, the copper content ranged from 0.33 to $0.69 \mathrm{mg} \mathrm{L}^{-1}$ with an average of $0.52 \mathrm{mg} \mathrm{L}^{-1}$, exceeding the permissible limits of Pakistani EPA and WHO standard values for drinking water, and FAO guidelines $\left(0.20 \mathrm{mg} \mathrm{L}^{-1}\right)$ for irrigation. The long-term irrigation from Rasul Barrage water may be avoided. The continuous irrigation of polluted water in terms of heavy metals may increase the available metals to plants, which could affect activities of soil microorganisms and, ultimately, human health [49].

\section{Fish Fauna}

The composition of the fish assemblage (families, genera, and species) sampled from Rasul Barrage is shown in Table 6. A total of 35 fish species were collected belonging to eight families. The composition of the fauna predominantly belonged to the Cyprinidae family ( $68.3 \%$ of the total), while $31.7 \%$ was contributed by all other families. These results were in accordance with the previous study conducted on the Jhelum in Pakistan [26] and the Ken River in India [50]. Fish data was analyed for abundance status of fish species by species percentages. On the basis of abundance, species were categorised in four groups: more than 3\% (abundant), 2.1-3\% (common), $0.51-2 \%$ (less common), and less than $0.5 \%$ (rare). Out of 35 fish species, 14 were classified as abundant, four common, 15 less common, and two as rare species (Table 4). Osteobrama cotio and Salmophasia bacaila showed the highest relative abundance of 12.63 and $11.21 \%$, respectively. In a previous study these species were also found to be abundant [26]. Gibelion catla and Bagarius fbagarius were categorized as rare species with lowest relative abundance of $0.35 \%$.

Geographically, the highest relative abundance $(23.84 \%)$ was recorded from the left bank pond area, whereas the old head work left bank showed lowest relative abundance $(11.56 \%)$. The relative abundance order of fish fauna at the reservoir was pond area $>$ downstream $>$ old head works.

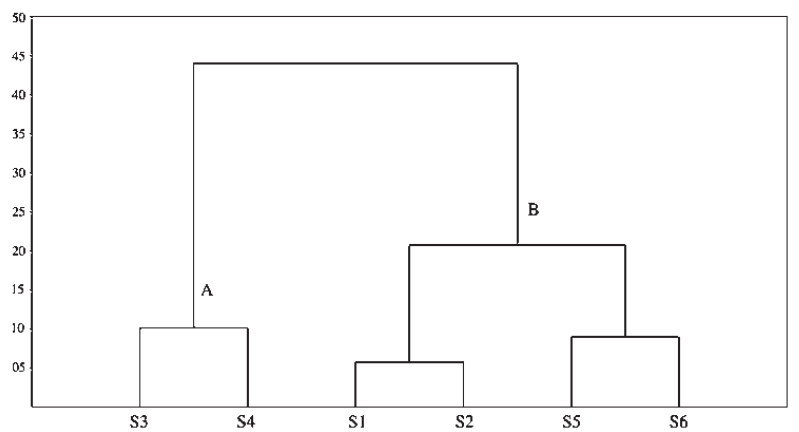

Fig. 2. Binary tree (dendrogram) showing the site grouping on the basis of fish abundance.
Table 5. Richness (S), evenness (E), Shannon diversity (H), and Simpson's diversity (D) indices of fish fauna at different sites of Rasul Barrage.

\begin{tabular}{|c|c|c|c|c|c|c|}
\hline Name & Total & $\begin{array}{c}\text { Max. } \\
\text { Ind }\end{array}$ & S & E & H & D \\
\hline S1 & 65 & 8 & 15 & 0.8653 & 2.563 & 0.915 \\
\hline S2 & 66 & 8 & 13 & 0.8694 & 2.425 & 0.905 \\
\hline S3 & 134 & 18 & 25 & 0.7633 & 2.949 & 0.9357 \\
\hline S4 & 124 & 23 & 24 & 0.6662 & 2.772 & 0.9119 \\
\hline S5 & 89 & 13 & 16 & 0.8264 & 2.582 & 0.9133 \\
\hline S6 & 84 & 9 & 23 & 0.8263 & 2.945 & 0.9393 \\
\hline
\end{tabular}

A strong negative correlation was observed between fish fauna and heavy metals concentrations. The data was subjected to cluster analysis to understand the similarities between sampling sites (Fig. 2). Cluster analysis grouped the sites in two major groups: A and B. These clusters were grouped on the basis of fish abundance. The first group was represented by two sites: S3 and S4 (pond area left and left banks). The second group was represented by S1 and S2 (old head works right and left banks) and S5 and S6 (downstream right and left banks). In general, the first group represented high fish richness and higher fish catch. It was observed that the pond area (S3 and S4) was more diverse than downstream and the old head works. This could be due to lower concentrations of metals in contrast to downstream and the old head works areas. It is well established that the higher concentration of metals may have lethal and sub-lethal effects on fish. To reduce contact to contaminants, aquatic organisms move from highly contaminated to less polluted areas.

Diversity indices were calculated using fish abundance data and results are represented in Table 5. Maximum species richness (25) was recorded at pond area left bank, whereas the minimum (13) was at the old headwork right bank. Similarly, Shannon's diversity index and Simpson's diversity indices were found to be highest at pond areas and minimum at old head works. The results of the present study revealed that the fish of Rasul Barrage are undergoing substantial changes due to anthropogenic activities, including construction of Mangla Dam on the Jhelum and unchecked disposal of waste [26]. It is considered that in the riverine system, natural flow regimes are an important factor for controlling fish assemblages [51]. Flow regimes are changed due to establishments of dams or barrages and greatly impact ecological activities in aquatic environments [52]. Furthermore, the absence of fish ladders in Rasul Barrage restricts fish movement to downstream and upstream, which can be one of the reasons for less fish. In addition, non-stop fishing might be a factor in reducing the ichthyofauna of the study area. 


\section{Conclusions}

It is concluded that such physicochemical parameters as $\mathrm{pH}$, temperature, TDS, sodium, and chlorides were under permissible limits of NEQS, whereas, TSS, BOD, and COD were higher than the standards set by the U.S. EPA. Moreover, concentrations of metals such as $\mathrm{Fe}, \mathrm{Cr}$, and $\mathrm{Ni}$ were higher than the safe limits for drinking and irrigation water. Additionally, results revealed that species richness was higher in pond areas with less concentration of metals while areas with higher metal contents (i.e., old head works and downstream) showed lower species richness. Therefore, it can be established that the higher concentration of metals may have affected the fish drastically. During the survey we also observed that the Rasul Barrage was constructed without fish ladders that restrict the movement of fish to upstream and downstream. Resultantly, the absence of fish ladders and non-stop fishing may be another reason for the reduction of fish. Two exotic fish species, Oreochromismossambicus and Ctenopharyngodonidella, were captured in the present study. The population of this species has increased and may have exerted negative impacts on the population of native fish fauna. Therefore, it is concluded that fish fauna of Rasul Barrage faced multiple problems such as over harvesting, fishing in banned periods, and fishing by electric current. These apportionment results may be useful to the governmental bodies/local authorities for pollution control of surface waters.

\section{Acknowledgment}

Authors acknowledge the University of the Punjab, New campus, Lahore, Pakistan for financial support of the present study.

\section{References}

1. BORAN M., ALTINOK I. A review of heavy metals in water, sediment and living organisms in the Black Sea. Turkish. J. Fish. Aquat. Sci. 10 (4), 2010.

2. CHAHARLANG B.H., BAKHTIARI A.R., YAVARI V. Assessment of cadmium, copper, lead and zinc contamination using oysters (Saccostrea cucullata) as biomonitors on the coast of the Persian Gulf, Iran. Bull. Environ. Contam. Toxicol. 88 (6), 956, 2012.

3. SHARIATI F., SARI A.E., MASHINCHIAN A., POURKAZEMI M. Metallothionein as potential biomarker of cadmium exposure in Persian sturgeon (Acipenser persicus). Biol. Trace. Elem. Res. 143 (1), 281, 2011.

4. MUBEDI J.I., DEVARAJAN N., LE FAUCHEUR S., MPUTU J.K., ATIBU E.K., SIVALINGAM P., PRABAKAR K., MPIANA P.T., WILDI W., POTÉ J. Effects of untreated hospital effluents on the accumulation of toxic metals in sediments of receiving system under tropical conditions: case of South India and Democratic Republic of Congo. Chemosphere. 93 (6), 1070, 2013.

5. PRITCHARD M., MKANDAWIRE T., O'NEILL J. Assessment of groundwater quality in shallow wells within the southern districts of Malawi. Phys. Chem. Earth. Pt A/B/C. 33 (8), 812, 2008.

6. SUTHAR S., NEMA A.K., CHABUKDHARA M., GUPTA S.K. Assessment of metals in water and sediments of Hindon River, India: impact of industrial and urban discharges. J. Hazard. Mater. 171 (1), 1088, 2009.

7. IQBAL H.H., TASEER R., ANWAR S., SHAHID N. Human health risk assessment: Consumption of heavy metals contaminated vegetables in Bahawalpur, Pakistan. Bull. Environ. Stud. 1 (1), 9, 2016.

8. ALYAHYA H., EL-GENDY A.H., AL FARRAJ S., ELHEDENY M. Evaluation of heavy metal pollution in the Arabian Gulf using the clam Meretrix meretrix Linnaeus, 1758. Water, Air, Soil. Pollut. 214 (1-4), 499, 2011.

9. ALI H., KHAN E., SAJAD M.A. Phytoremediation of heavy metals-concepts and applications. Chemosphere. 91 (7), 869, 2013.

10. COPAT C.,ARENA G., FIOREM., LEDDAC., FALLICO R., SCIACCA S., FERRANTE M. Heavy metals concentrations in fish and shellfish from eastern Mediterranean Sea: consumption advisories. Food Chem Toxicol. 53, 33, 2013.

11. HE B., YUN Z., SHI J., JIANG G. Research progress of heavy metal pollution in China: Sources, analytical methods, status, and toxicity. Chin. Sci. Bull. 58 (2), 134, 2013.

12. SINGH A., PAL R., GANGWAR C., GUPTA1S A., TRIPATHI A. Release of Heavy Metals from Industrial Waste and E-Waste Burning and Its Effect on Human Health and Environment. Int. J. Emerg. Res. Manag. Technol. 4 (12), 51, 2015.

13. KAILE B., NYIRENDA J. Assessing the Bioaccumulative Impact of Four Heavy Metals on the Endocrine System of Tilapia rendalli Fish Species in the Kafue River. Ann. Res. Rev. Biol. 9 (4), 1, 2016.

14. SREBOTNJAK T., CARR G., DE SHERBININ A., RICKWOOD C. A global Water Quality Index and hot-deck imputation of missing data. Ecol. Indicators. 17, 108, 2012.

15. ISLAM M.S., AHMED M.K., RAKNUZZAMAN M., HABIBULLAH-AL-MAMUN M., ISLAM M. K. Heavy metal pollution in surface water and sediment: a preliminary assessment of an urban river in a developing country. Ecol. Indicators. 48, 282, 2015.

16. SU S., XIAO R., MI X., XU X., ZHANG Z., WU J. Spatial determinants of hazardous chemicals in surface water of Qiantang River, China. Ecol Indicators. 24, 375, 2013.

17. SALEEM M., IQBAL J., SHAH M.H. Dissolved concentrations, sources, and risk evaluation of selected metals in surface water from mangla lake, Pakistan. Scientific. World. J. 2014, 2014.

18. EQANI S.A.-M.-A.-S., MALIK R.N., KATSOYIANNIS A., ZHANG G., CHAKRABORTY P., MOHAMMAD A., JONES K.C. Distribution and risk assessment of organochlorine contaminants in surface water from River Chenab, Pakistan. J. Environ. Monit. 14 (6), 1645, 2012.

19. JABEEN A., HUANG X., AAMIR M. The Challenges of Water Pollution, Threat to Public Health, Flaws of Water Laws and Policies in Pakistan. J. Water. Resource. Prot. 7 (17), 1516, 2015.

20. QADIR A., MALIK R.N., HUSAIN S.Z. Spatio-temporal variations in water quality of Nullah Aik-tributary of the river Chenab, Pakistan. Environ. Monit. Assess. 140 (1-3), 43, 2008.

21. AZMAT H., JAVED M., HUSSSAIN S.M., JAVID A., JABEEN G. Impacts of Physico-Chemical Parameters on Fish Grown Under Heavy Metal Stress. Pak. J. Zool. 48 (3), 795, 2016. 
22. SFAKIANAKIS D., RENIERI E., KENTOURI M., TSATSAKIS A. Effect of heavy metals on fish larvae deformities: a review. Environ. Res. 137, 246, 2015.

23. MALIK R.N., ZEB N. Assessment of environmental contamination using feathers of Bubulcus ibis L., as a biomonitor of heavy metal pollution, Pakistan. Ecotoxicology. 18 (5), 522, 2009.

24. AKBAR M., JANJUA A. Waterfowl population estimation at Rasool Barrage, Game Reserve, Jhelum, Pakistan (19962005). Pak. J. Life. Soc. Sci. 8 (1), 11, 2010.

25. SARWAR S., AHMAD F., KHAN J. Assessment of the quality of Jehlum river water for irrigation and drinking at district Muzaffarabad Azad Kashmir. Sarhad. J. Agric. 23 (4), 1041, 2007.

26. MIRZA Z.S., MIRZA M.R., MIRZA M., SULEHRIA A. Ichthyofaunal diversity of the River Jhelum, Pakistan. Biologia. 57 (1\&2), 23, 2011

27. APHA Standard methods for the examination of water and wastewater. American Public Health Association (APHA): Washington, DC, USA. 2005.

28. MOORE J. W., RAMAMOORTHY S. Heavy metals in natural waters: applied monitoring and impact assessment. 2012: Springer Science \& Business Media.

29. KUBEČKA J., GODØ O.R., HICKLEY P., PRCHALOVÁ M., ŘIHA M., RUDSTAM L., WELCOMME R. Fish sampling with active methods. Fisheries Res. 123, 1-3, 2012.

30. JEGA I.S., RIBAH I.M., IDRIS Z., HAQUE M.M., AZIZ M.S.B., ALAM M.M. Survey of some aspects of artisanal fisheries of Sabiyel lake, Aliero, Kebbi state, Nigeria. Res. Agric. Livest. Fish. 2 (3), 507, 2015.

31. REHMAN H.U., ULLAH A., REHMAN F.U., KHATTAK B., ULLAH S., ATLAS A., REHMAN J.U., ULLAH W. Biodiversity of Fish Fauna of Ghandiali Dam, District Kohat, Khyber Pakhtunkhwa, Pakistan. World. Appl. Sci. J. 33 (9), 1511, 2015.

32. MIRZA M., JAVED M. Fishes of the river Chenab in Pakistan. Biologia (Pakistan). 2003.

33. MAGURRAN A.E. Ecological diversity and its measurement. Springer Science \& Business Media. 2013

34. BAUDER T.A., WASKOM R.M., DAVIS J.G., SUTHERLAND P.L. Irrigation water quality criteria. Colorado State University Extension Fort Collins, CO, USA. 2011.

35. BHATT L., LACOUL P., LEKHAK H., JHA P. Physicochemical characteristics and phytoplanktons of Taudaha lake, Kathmandu. Pollut. Res. 18 (4), 353, 1999.

36. VALIPOUR A., HAMNABARD N., WOO K.-S., AHN Y.$\mathrm{H}$. Performance of high-rate constructed phytoremediation process with attached growth for domestic wastewater treatment: Effect of high TDS and $\mathrm{Cu}$. J. Environ. Manage. 145, 1-8, 2014.

37. WHO. Guidelines for drinking-water quality: recommendations. 1. 2004.

38. AGARWAL A. K.,RAJWAR G.S. Physico-chemical and microbiological study of Tehri dam reservoir, Garhwal Himalaya, India. J. Am. Sci. 6 (6), 65, 2010.
39. QUINTEIRO P., DIAS A.C., ARAÚJO A., PESTANA J.L., RIDOUTT B.G., ARROJA L. Suspended solids in freshwater systems: characterisation model describing potential impacts on aquatic biota. Int. J. Life. Cycle. Ass. 20 (9), 1232, 2015.

40. SHOJI J., MASUDA R., YAMASHITA Y., TANAKA M. Effect of low dissolved oxygen concentrations on behavior and predation rates on red sea bream Pagrus major larvae by the jellyfish Aurelia aurita and by juvenile Spanish mackerel Scomberomorus niphonius. Mar. Biol. 147 (4), 863, 2005.

41. LUCE J.J., STEELE R., LAPOINTE M.F. A physically based statistical model of sand abrasion effects on periphyton biomass. Ecol. Model. 221 (2), 353, 2010.

42. BILOTTA G., BRAZIER R. Understanding the influence of suspended solids on water quality and aquatic biota. Water. Res. 42 (12), 2849, 2008.

43. KAZI S.A., IQBAL H.H., SHAHID N., SHAH G.M., JAMEEL N. Removal of Reactive Dye Yellow 145 by Adsorption Using White Quartz. Bull. Environ. Stud. 1 (2), 43, 2016.

44. KARAR K., GUPTA A., KUMAR A., BISWAS A.K. Characterization and identification of the sources of chromium, zinc, lead, cadmium, nickel, manganese and iron in PM10 particulates at the two sites of Kolkata, India. Environ. Monit. Assess. 120 (1-3), 347, 2006.

45. KRAUSE-NEHRING J., BREY T., THORROLD S.R. Centennial records of lead contamination in northern Atlantic bivalves (Arctica islandica). Mar. Pollut. Bull. 64 (2), 233, 2012.

46. KUMARI M., PITTMAN C.U., MOHAN D. Heavy metals [chromium (VI) and lead (II)] removal from water using mesoporous magnetite $\left(\mathrm{Fe}_{3} \mathrm{O}_{4}\right)$ nanospheres. J. Colloid. Interface. Sci. 442, 120-132, 2015.

47. HAMID A., ZEB M., MEHMOOD A., AKHTAR S., SAIF S. Assessment of wastewater quality of drains for irrigation J. Environ. Protec. 4 (09), 937, 2013.

48. SINGH K.P., MALIK A., SINHA S., SINGH V.K., MURTHY R.C. Estimation of source of heavy metal contamination in sediments of Gomti River (India) using principal component analysis. Water. Air. Soil. Pollut. 166 (1-4), 321, 2005.

49. PANDA U.C., RATH P., SAHU K.C., MAJUMDAR S., SUNDARAY S.K. Study of geochemical association of some trace metals in the sediments of Chilika lake: A multivariate statistical approach. Environ. Monit. Assess. 123 (1-3), 125, 2006.

50. JOHNSON J., PARMAR R., RAMESH K., SEN S., MURTHY R.S. Fish diversity and assemblage structure in Ken River of Panna landscape, central India. Journal of Threatened Taxa. 4 (13), 3161, 2012.

51. CHURCH M. Geomorphic thresholds in riverine landscapes. Freshwat. Biol. 47 (4), 541, 2002.

52. YOON J.-D., JANG M.-H., JO H.-B., JEONG K.-S., KIM G.-Y., JOO G.-J. Changes of fish assemblages after construction of an estuary barrage in the lower Nakdong River, South Korea. Limnology. 17 (2), 183, 2016. 